\title{
EVALUATION OF OXIME K203 AS ANTIDOTE IN TABUN POISONING
}

\author{
Zrinka KOVARIK ${ }^{1}$, Ana LUCIĆ VRDOLJAKㄴ, Suzana BEREND ${ }^{1}$, Maja KATALINIĆ ${ }^{\text {, }}$ \\ Kamil KUČA ${ }^{2}$, Kamil MUSILEK ${ }^{2}$, and Božica RADIĆ ${ }^{1}$ \\ Institute for Medical Research and Occupational Health, Zagreb, Croatial', Center of Advanced Studies, \\ Faculty of Military Health Sciences, Hradec Kralove, Czech Republic ${ }^{2}$
}

Received in June 2008

Accepted in October 2008

\begin{abstract}
We studied bispyridinium oxime K203 [(E)-1-(4-carbamoylpyridinium)-4-(4-hydroxyiminomethylpyridinium)-but-2-ene dibromide] with tabun-inhibited human acetylcholinesterase (AChE) and butyrylcholinesterase (BChE) in vitro, and its antidotal effect on tabun-poisoned mice and rats in vivo. We compared it with oximes K048 and TMB-4, which have proven the most efficient oxime antidotes in tabun poisoning by now. Tabun-inhibited AChE was completely reactivated by K203, with the overall reactivation rate constant of $1806 \mathrm{~L} \mathrm{~mol}^{-1} \mathrm{~min}^{-1}$. This means that $\mathrm{K} 203$ is a very potent reactivator of tabun-inhibited AChE. In addition, K203 reversibly inhibited AChE $\left(K_{\mathrm{i}}=0.090 \mathrm{mmol} \mathrm{L}^{-1}\right)$ and BChE $\left(K_{\mathrm{i}}=0.91 \mathrm{mmol} \mathrm{L}^{-1}\right)$, and exhibited its protective effect against phosphorylation of AChE by tabun in vitro. In vivo, a quarter of the $\mathrm{LD}_{50} \mathrm{~K} 203$ dose insured survival of all mice after the application of as many as $8 \mathrm{LD}_{50}$ doses of tabun, which is the highest dosage obtained compared to K048 and TMB-4. Moreover, K203 showed high therapeutic potency in tabun-poisoned rats, preserving cholinesterase activity in rat plasma up to $60 \mathrm{~min}$ after poisoning. This therapeutic improvement obtained by K203 in tabun-poisoning places this oxime in the spotlight for further development.
\end{abstract}

KEY WORDS: acetylcholinesterase, bioscavenger, butyrylcholinesterase, K048, nerve agents, TMB-4, pyridinium oxime

Pyridinium oximes have been investigated for many years as compounds with a great potential in the treatment of poisoning with organophosphorus compounds, including insecticides and nerve agents (1). One of the most important actions of oximes is that they reactivate acetylcholinesterase (AChE; EC 3.1.1.7) inhibited by organophosphorus agents. In restoring the activity of $\mathrm{AChE}$, oximes may also have beneficial antinicotinic effects (2-4). Current evidence indicates that atropine is favourable only in the management of acute muscarinic signs and symptoms (sweating, salivation, rhinorrhoe, lacrimation, nausea, vomiting, and diarrhoea) induced by organophosphates $(2,5-7)$. Although atropine does not readily cross the blood-brain barrier, in combination with oximes it is the treatment of choice for organophosphate poisoning $(7,8)$. Unfortunately, some organophosphates resist standard antidotal treatment (1). One of the most dangerous organophosphates is nerve agent tabun. The inability of the standard therapy to reactivate tabun-phosphorylated AChE may be due to the lower electrophilicity of the phosphoroamidate conjugated to the AChE active site (9). While oxime HI-6 cannot reactivate tabun-inhibited enzyme, although it exerts a significant protection via different mechanisms (10), HLö-7 can actually reactivate AChE inhibited by all four main nerve agents (tabun, sarin, soman and VX). Oxime TMB-4 effectively reactivates tabun-inhibited $\mathrm{AChE}$, and it also reduces or alleviates the toxic effects of tabun, showing beneficial effects in the treatment 
of tabun-poisoned animals $(1,11,12)$. At the same time, TMB-4 is the most toxic oxime of the four most investigated oximes 2-PAM, HI-6, obidoxime, and TMB-4 (4). Therefore, there is still a need to develop not only the most effective, but also the least toxic organophosphate antidote.

Recently we obtained promising results on in vitro reactivation of human $\mathrm{AChE}$ inhibited by tabun and antidotal treatment of tabun-poisoned mice with bispyridinium oximes (13-18). In this paper we tested the reactivation and antidotal potency of bispyridinium oxime $\mathrm{K} 203$, which is an analogue of the most efficient oxime from our previous studies, K048 (Figure 1) (13, 14). We determined in vitro kinetic parameters for K203 interactions (inhibition and reactivation) with native and tabun-inhibited human erythrocyte $\mathrm{AChE}$ and human plasma butyrylcholinesterase (BChE; EC 3.1.1.8). BChE was included in the study to evaluate oxime interaction with this endogenous bio-scavenger, because it could interfere with the reactivation of tabun-inhibited AChE. The antidotal effect of K203 upon tabun-poisoning was studied in mice. Rats were used to study temporal and spatial distribution of the cholinesterase activity after exposure to tabun.

\section{MATERIAL AND METHODS}

\section{Chemicals}

Figure 1 shows the structure of oximes K203, K048, and TMB-4 and tabun. K203 [(E)1-(4-carbamoylpyridinium)-4-(4-hydroxyiminomethylpyridinium)-but-2-ene dibromide] was prepared as described earlier (19). Tabun [ethyl $\mathrm{N}, \mathrm{N}$-dimethylphosphoroamidocyanidate] was purchased from NC Laboratory, Spiez, Switzerland. Acetylthiocholine iodide (ATCh) and 5,5'-dithiobis(2nitrobenzoic acid) (DTNB) were purchased from Sigma Chemical Co., St. Louis, MO, USA. Atropine sulphate was purchased from Kemika, Zagreb, Croatia.

\section{Cholinesterases and activity measurement}

Intact native human erythrocytes were the source of AChE, while the source of $\mathrm{BChE}$ was native human plasma (usual phenotype). AChE and $\mathrm{BChE}$ reversible inhibition, protection against tabun progressive inhibition, and reactivation of tabun-inhibited cholinesterases by K203 were measured spectrophotometrically as described

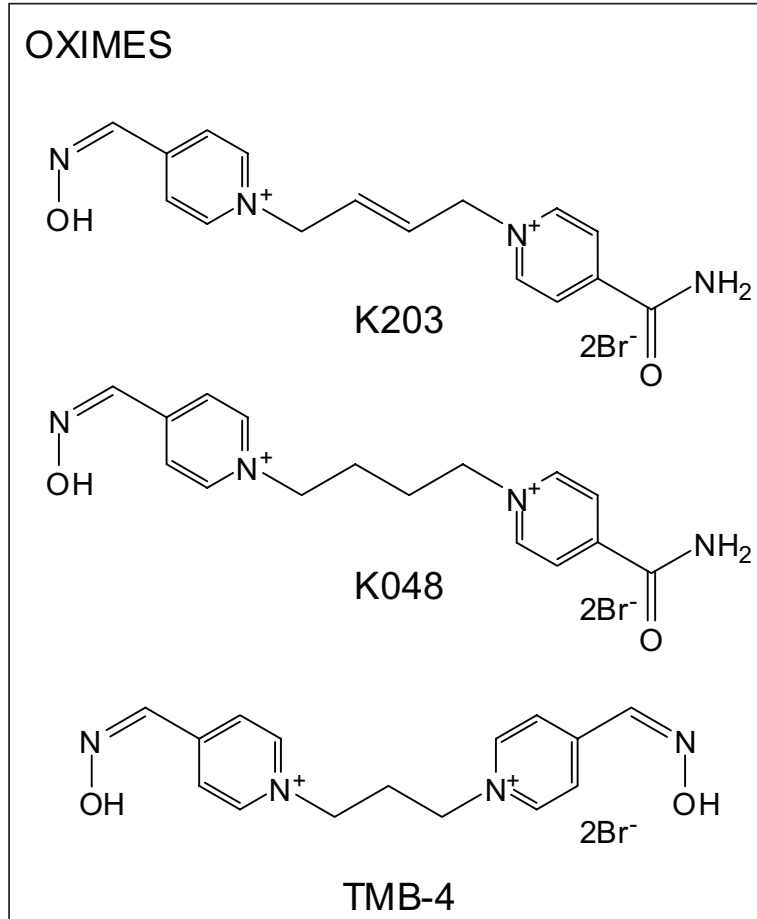

ORGANOPHOSPHORUS COMPOUND<smiles>CCOP(=O)(C=N)N(C)C</smiles>

Tabun

Figure 1 Structure of the tested oximes and tabun.

earlier $(13,14)$. Kinetic parameters were calculated from experimental data obtained in at least three experiments using known equations $(13-15,20)$. We evaluated the following kinetic parameters: secondorder rate constant of the non-enzymatic reaction $\left(k_{\mathrm{NE}}\right)$, enzyme-oxime dissociation constant $\left(K_{\mathrm{i}}\right)$, enzyme-substrate dissociation constant corresponding to Michaelis constant $\left(K_{\mathrm{m}}\right)$, protection by oxime against phosphorylation in terms of calculated and experimentally obtained protective index ( $\mathrm{PI}_{\text {calc }}, \mathrm{PI}_{\text {exp }}$ ), maximum first-order rate constant of reactivation $\left(k_{\max }\right)$, phosphorylated enzyme-oxime dissociation constant $\left(K_{\mathrm{OX}}\right)$, and overall second-order rate constant of reactivation $\left(k_{\mathrm{r}}\right)$.

All experiments were done in $0.1 \mathrm{~mol} \mathrm{~L}^{-1}$ sodium phosphate buffer, $\mathrm{pH} 7.4$, at $25^{\circ} \mathrm{C}$. The final plasma dilution in the experiments was 200 to 300 fold, 
while the final dilution of erythrocytes was 400 fold. Final oxime and ATCh concentrations used in the experiments, stated in Table 1, were chosen so that the oxime induced ATCh hydrolysis did not interfere with the studied interactions $(21,22)$.

\section{Animals}

Male BALB-C mice [(18 to 25$) \mathrm{g}$ body weight] were purchased from the Institute of Immunology, Zagreb, Croatia, while male adult Wistar rats [(240 to 280) g body weight] were obtained from the Institute for Medical Research and Occupational Health, Zagreb, Croatia. The animals were kept in Macrolone cages under controlled conditions (room temperature $21{ }^{\circ} \mathrm{C}$, exchanging light and dark cycles every $12 \mathrm{~h}$ ), received standard diet for laboratory rodents, and had free access to water. Both mice and rats were randomly distributed in groups of four and were deprived of food for $24 \mathrm{~h}$ before the experiment. This study was performed with the approval of the Ethical Committee of the Institute for Medical Research and Occupational Health, Zagreb, Croatia.

\section{Acute toxicity}

Acute intraperitoneal (i.p.) toxicity $\left(\mathrm{LD}_{50}\right)$ for all tested oximes was evaluated in mice and rats. It was based upon $24 \mathrm{~h}$ mortality rates calculated according to Thompson (23) and Weil (24). Each $\mathrm{LD}_{50}$ was evaluated from the results obtained with (4 to 6 ) doses of a given compound (dissolved in water); four animals were injected per dose. Whenever the results of the experiment allowed, the $95 \%$ confidence limits were estimated from tables described elsewhere (23, 24).

Therapeutic effect of K203 against tabun poisoning in mice

The therapeutic effect of K203 in mice was tested by i.p. administration of $\mathrm{K} 203\left(1 / 4\right.$ of its $\left.\mathrm{LD}_{50}\right)$ and atropine sulphate $\left(10 \mathrm{mg} \mathrm{kg}^{-1}\right)$ one minute after subcutaneous tabun administration. Stock solution of $3.1 \times 10^{-2} \mathrm{~mol} \mathrm{~L}^{-1}$ of tabun was prepared in isopropyl alcohol; further dilutions were made in water, shortly before use. The antidotal efficacy of K203 was expressed as protective index (PI) with $95 \%$ confidence limits, and maximal dose of poison (MDP). The PI was the ratio of $L D_{50}$ of tabun with and without therapy. The MDP was the highest multiple of the $\mathrm{LD}_{50}$ of tabun, which was fully counteracted (survival of all animals) by the administrated therapy.

\section{Treatment with K203 in tabun-poisoned rats}

For the temporal and spatial distribution of cholinesterase activity, rats received a subcutaneous dose of $3 / 4 \mathrm{LD}_{50}$ of tabun $\left(\mathrm{LD}_{50}=315.5 \mu \mathrm{g} \mathrm{kg}^{-1}\right.$ body weight). The therapeutic efficacy of K203 (1/4 of its $\mathrm{LD}_{50}$ dose, i.p.) was tested as therapy given in combination with atropine one minute after tabun poisoning. Animals were sacrificed using the $\mathrm{CO}_{2}$ box $10 \mathrm{~min}, 30 \mathrm{~min}, 60 \mathrm{~min}$, and $24 \mathrm{~h}$ after the treatment. Blood samples were obtained directly from the heart. Brain was also isolated and rinsed with saline. Plasma and brain samples were frozen immediately after sampling at $-20{ }^{\circ} \mathrm{C}$ until further processing. Prior to enzyme activity measurements, brain samples were homogenised $\left(40 \mathrm{mg} \mathrm{mL}^{-1}\right)$ in saline. Plasma samples were used untreated.

The activity of cholinesterases in plasma and in brain homogenates was determined spectrophotometrically, using the method by Ellman et al. (25). All experiments were performed in $0.1 \mathrm{~mol} \mathrm{~L}^{-1}$ phosphate buffer (pH 7.4), and enzyme activities were measured in the presence of $1.0 \mathrm{mmol} \mathrm{L}^{-1}$ ATCh at $22{ }^{\circ} \mathrm{C}$. The measured activity presented total $\mathrm{AChE}$ and $\mathrm{BChE}$ activity in plasma or the brain.

Statistical significance was determined using Student's $t$-test, and differences were considered significant when $P<0.05$.

\section{RESULTS AND DISCUSSION}

\section{In vitro K203 interactions with cholinesterases}

A newly introduced oxime K203 was evaluated through a series of in vitro experiments with an aim to establish its potency to counteract tabun poisoning in vivo. We established relevant properties of K203 using kinetic parameters such as inhibition of native and reactivation of tabun-inhibited human erythrocyte $\mathrm{AChE}$ and human plasma BChE. Summarised results are presented in Table 1.

K203 reversibly inhibited both cholinesterases and in the studied concentration range of substrate ATCh, the binding to the catalytic site of both $\mathrm{AChE}$ and $\mathrm{BChE}$ was competitive. Possible binding to the allosteric site could not be determined due to the interference of the non-enzymatic reaction between K203 and the substrate with enzyme activity measurement $\left(k_{\mathrm{NE}}\right.$ in Table 1; 22). K203 showed a significant preference for native $\mathrm{AChE}$, which points out its potential to 
Table 1 Interactions between bispyridinium para-oxime K203 and native and tabun-inhibited human AChE and BChE. Constants (mean \pm standard errors) and protective indices (mean \pm standard deviation) were calculated from experimental data obtained in at least three experiments.

\begin{tabular}{|c|c|c|}
\hline \multicolumn{3}{|c|}{ Non-enzymatic reaction of K203 with substrate ATCh } \\
\hline & $\mathrm{K} 203 / \mathrm{mmol} \mathrm{L}^{-1}$ & $\mathrm{ATCh} / \mathrm{mmol} \mathrm{L}^{-1}$ \\
\hline & 0.012 to 1.0 & 0.05 to 2.0 \\
\hline$k_{\mathrm{NE}} / \mathrm{L} \mathrm{mol}^{-1} \mathrm{~min}^{-1}$ & \multicolumn{2}{|c|}{$13.1 \pm 0.27$} \\
\hline \multicolumn{3}{|c|}{ Inhibition of native enzymes } \\
\hline & AChE & $\mathrm{BChE}$ \\
\hline$K_{\mathrm{i}} / \mathrm{mmol} \mathrm{L}^{-1}$ & $0.090 \pm 0.012$ & $0.91 \pm 0.16$ \\
\hline$K_{\mathrm{m}} / \mathrm{mmol} \mathrm{L}^{-1}$ & $0.42 \pm 0.071$ & $0.14 \pm 0.029$ \\
\hline $\mathrm{K} 203 / \mathrm{mmol} \mathrm{L}^{-1}$ & 0.05 to 0.50 & 0.50 to 2.0 \\
\hline $\mathrm{ATCh} / \mathrm{mmol} \mathrm{L}^{-1}$ & 0.10 to 1.0 & 0.05 to 0.50 \\
\hline \multicolumn{3}{|c|}{ Protection against phosphorylation by tabun } \\
\hline & \multicolumn{2}{|c|}{$\mathrm{AChE}$} \\
\hline $\mathrm{K} 203 / \mathrm{mmol} \mathrm{L}^{-1}$ & \multicolumn{2}{|c|}{0.090} \\
\hline $\mathrm{PI}_{\text {calc }}$ & \multicolumn{2}{|c|}{2.0} \\
\hline $\mathrm{PI}_{\exp }$ & \multicolumn{2}{|c|}{$2.08 \pm 0.02$} \\
\hline \multicolumn{3}{|c|}{ Reactivation of tabun-inhibited enzymes } \\
\hline & $\mathrm{AChE}$ & $\mathrm{BChE}$ \\
\hline $\mathrm{K} 203 / \mathrm{mmol} \mathrm{L}^{-1}$ & 0.01 to 1.0 & 0.10 to 3.0 \\
\hline$k_{\mathrm{r}} / \mathrm{L} \mathrm{mol}^{-1} \mathrm{~min}^{-1}$ & $1806 \pm 491$ & $1.20 \pm 0.50$ \\
\hline$K_{\mathrm{ox}} / \mathrm{mmol} \mathrm{L}^{-1}$ & $0.072 \pm 0.019$ & $2.30 \pm 0.80$ \\
\hline$k_{\max } / \min ^{-1}$ & $0.13 \pm 0.01$ & $0.003 \pm 0.0005$ \\
\hline React $_{\max } / \%$ & 90 & 30 \\
\hline Time of React ${ }_{\max }$ & $20 \mathrm{~min}$ & $6 \mathrm{~h}$ \\
\hline
\end{tabular}

reach the main biological target in vivo in tabun poisoning. Among the oximes we tested, the AChEoxime dissociation constant, $K_{\mathrm{i}}$, of $0.09 \mathrm{mmol} \mathrm{L}^{-1}$, shows K203 as a moderate AChE inhibitor (15). This finding may indicate lower acute toxicity of K203, as our previous results have shown that binding affinity in vitro corresponds to toxicity in vivo (13).

We also determined the protective effect of K203 by measuring progressive $\mathrm{AChE}$ inhibition by tabun in the absence and in the presence of the oxime in the concentration corresponding to $K_{\mathrm{i}}$ (Table 1). K203 halved the rate of $\mathrm{AChE}$ inhibition by tabun ( $\mathrm{PI}_{\text {exp }}$ ), which means that if used in pretreatment in vivo, it should be able to protect the AChE active site from tabun inhibition.
K203-assisted reactivation of tabun-inhibited $\mathrm{AChE}$ was very efficient. A high percentage of reactivation was achieved in a short time, even when a lower concentration of K203 was applied. In order to get a clearer interpretation of $\mathrm{K} 203$ reactivation efficacy, we compared the result with the one obtained for the most potent reactivator from our previous studies, K048 and TMB-4 as a reference compound $(13,14)$. The overall reactivation rate constant, $k_{\mathrm{r}}$, of $1806 \mathrm{~L} \mathrm{~mol}^{-1} \mathrm{~min}^{-1}$ sets K203 high above K048 $\left(k_{\mathrm{r}}=673 \mathrm{~L} \mathrm{~mol}^{-1} \mathrm{~min}^{-1}\right)(13)$ or TMB-4 $\left(k_{\mathrm{r}}=306 \mathrm{~L}\right.$ $\left.\mathrm{mol}^{-1} \mathrm{~min}^{-1}\right)(20)$. The main reason for this advantage lies in a combination of higher affinity for phosphorylated $\operatorname{AChE~}\left(1 / K_{\mathrm{OX}} ; K_{\mathrm{OX}}=0.07 \mathrm{mmol} \mathrm{L}^{-1}\right)$ and the fast rate of the nucleophilic displacement of the phosphorylmoiety from the active site serine $\left(k_{\max }=0.13\right.$ $\left.\min ^{-1}\right)$. Figure 2 shows the reactivation achieved with $0.10 \mathrm{mmol} \mathrm{L}^{-1}$ of each oxime in $30 \mathrm{~min}$ and the rate of reactivation at that concentration $\left(k_{\mathrm{obs}}\right)$. Interestingly, the only structural difference between K203 and K048, which was the most efficient oxime in our previous studies, is a double bond present in the $\mathrm{K} 203$ linker. However, this double bond could influence the flexibility of a linker and the formation of additional bonds in the active sites, which in the case of K203 resulted in an efficient reactivation.

Like other previously tested oximes, K203 showed no significant reactivation of tabun-inhibited $\mathrm{BChE}$ $(14,16)$. Even after $20 \mathrm{~h}$, the reactivation maximum was only $30 \%$. This means that the fast K203-assisted reactivation of tabun-inhibited $\mathrm{AChE}$ would not be slowed down by $\mathrm{K} 203$ interactions with $\mathrm{BChE}$ in vivo.

\section{Oxime K203 as antidote in mouse and rat tabun poisoning}

Table 2 summarises the acute toxicity of the tested oximes after intraperitoneal administration. The acute toxicity of K203 was almost two times lower in rats than in mice. A similar result was obtained for TMB-4. This is quite unexpected since our previous experience with experimental animals has shown that rats are more sensitive to xenobiotics than mice. Oxime K203 showed lower acute toxicity than TMB-4 in mice, but a little higher than TMB-4 in rats. Low toxicity of $\mathrm{K} 048$ in rats corresponds to its previously determined toxicity in mice (13).

In vivo experiments included the evaluation of antidotal efficiency of oxime K203 in tabun-poisoned mice. We tested the antidotal efficacy of K203 at $1 / 4$ of its $\mathrm{LD}_{50}$, and results were compared with our previous 
Table 2 Acute toxicity $\left(L D_{50}\right)$ of the tested oximes following i.p. administration in mice and rats. In parenthesis: $95 \%$ confidence limit.

\begin{tabular}{lcc}
\hline \multirow{2}{*}{ Oximes } & \multicolumn{2}{c}{$\mathbf{L D}_{\mathbf{5 0}} / \mathbf{~ m g ~ k g}^{-1}$} \\
\cline { 2 - 3 } & Mice & Rats \\
\hline K203 & $89.1(75.7$ to 104.9$)$ & $168.2(149.9$ to 188.8$)$ \\
K048 & $224.8(154.2 \text { to } 328.0)^{*}$ & $238.3(199.7$ to 284.3$)$ \\
TMB-4 & $73.5(56.0 \text { to } 96.5)^{*}$ & $178.2(164.2$ to 193.4$)$ \\
\hline
\end{tabular}

* From ref. 13.

Table 3 Effect of the oxime plus atropine combination on subcutaneous tabun toxicity in male mice.

\begin{tabular}{lcccc}
\hline Treatment & $\begin{array}{c}\mathbf{L D}_{\mathbf{5 0}} / \\
\boldsymbol{\mu g ~ k g}^{-1}\end{array}$ & $\begin{array}{c}\mathbf{9 5} \text { \% confidence limit / } \\
\mathbf{\mu g ~ k g}^{-1}\end{array}$ & PI & MDP \\
\hline Atropine* & 401.0 & 356.0 to 477.0 & 1.5 & 1.0 \\
K203 + atropine & 3202.6 & 2452.3 to 4182.4 & 9.0 & 8.0 \\
K048 + atropine* & 2853.0 & 2427.7 to 3352.7 & 8.0 & 5.0 \\
TMB-4 + atropine* & 2542.0 & 1759.0 to 3672.0 & 7.0 & 5.0 \\
\hline
\end{tabular}

* From ref. 13 ( $\mathrm{LD}_{50}$ of tabun was $\left.356.6 \mu \mathrm{g} \mathrm{kg}^{-1}\right)$

$P I$ - protective index

$M D P$ - maximal dose of tabun

findings for oximes K048 and TMB-4 $(13,14)$. A combination therapy with K203 and atropine given one minute after tabun poisoning provided particularly good protection of mice from tabun-induced seizures and from toxic effects associated with muscarinic receptors, such as salivation, lacrimation, diarrhea, and other secretory activities. The protective index of this combined therapy was $9.0 \mathrm{LD}_{50}$, and all experimental animals survived at as high tabun dose as $8.0 \mathrm{LD}_{50}$. In addition, it considerably lowered tabun-induced acute toxicity in mice. Compared to K048 and TMB-4, K203 seems to be the most effective in tabun-poisoned mice, regardless of its relative toxicity. In addition, a good reactivating efficacy of K203 in vitro (cf. Table 1) corresponds to its therapeutic efficacy in mice in vivo (cf. Table 3). Therefore, it seems that this compound has indeed a therapeutic effect that is related to the reactivation of tabun-phosphorylated $\mathrm{AChE}$.

In this study, we extended our in vivo experiments to rats, poisoning them with a single sub-lethal subcutaneous dose of tabun $\left(3 / 4\right.$ of its $\left.\mathrm{LD}_{50}\right)$. Signs of toxicity such as convulsions, hypersalivation, muscle fasciculation, seizures, and fine tremor appeared within $5 \mathrm{~min}$ to $10 \mathrm{~min}$. Signs of toxicity peaked 15 $\mathrm{min}$ to $60 \mathrm{~min}$ after tabun injection. Figure 3 shows the effect of K203 combined with atropine on rat plasma and brain activity of the cholinesterases. A decrease in both plasma and brain was measured in all animals administered $3 / 4 \mathrm{LD}_{50}$ of tabun. A combination of $\mathrm{K} 203$ (in a dose of $1 / 4$ of its $\mathrm{LD}_{50}$ ) and atropine (i.p.) seems to be effective in restoring the activity of the

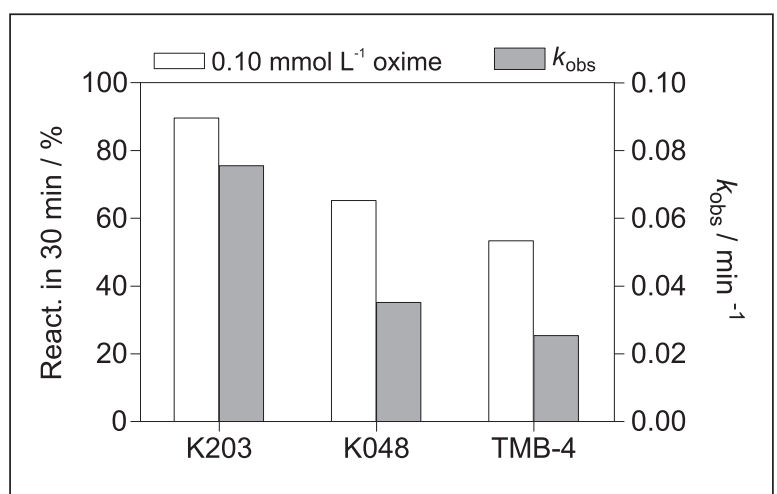

Figure 2 Oxime-assisted reactivation of tabun-inhibited human erythrocyte AChE (\%) obtained at $30 \mathrm{~min}$ and observed reactivation rate constant $\left(\mathrm{k}_{\text {obs }}\right)$ with $0.10 \mathrm{mmol} \mathrm{L}^{-1}$.

cholinesterases in plasma if administered one minute after tabun poisoning. This combination significantly increased enzyme activity at $30 \mathrm{~min}$ and $60 \mathrm{~min}$ $(P<0.05)$, in respect to untreated rats poisoned with $3 / 4 \mathrm{LD}_{50}$ of tabun (Figure 3a). After $6 \mathrm{~h}$, the effect of the therapy diminished; enzyme activity in plasma was as low as in tabun-poisoned rats, probably due to a relatively short oxime blood circulation time (28). After $24 \mathrm{~h}$, plasma activities in either poisoned or treated rats were high, probably because $\mathrm{AChE}$ and/or $\mathrm{BChE}$ were synthesized de novo, and tabun was eliminated from the organism. Interestingly, brain AChE activity did not differ significantly between poisoned and treated rats (Figure 3b). Due to the positive oxime charge and oxime's limiting penetration capacity through the blood-brain barrier, 


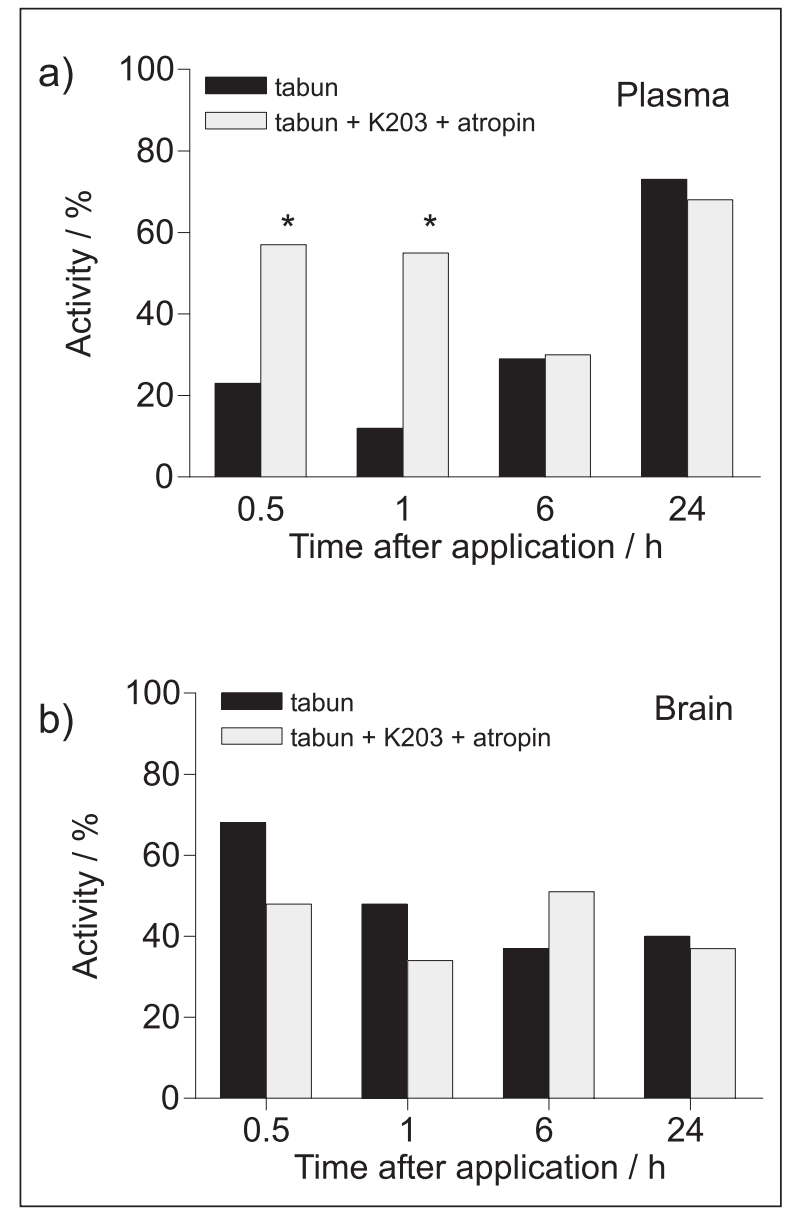

Figure 3 The effects of K203 given in combination with atropine on the activity of cholinesterases in the plasma (a) and brain (b) of tabun-poisoned rats. Asterisk denotes significantly increased enzyme activity in respect to control $(P<0.05)$.

K203 was not sufficiently effective in protecting the brain.

In conclusion, all of the results presented here demonstrate the high potency of K203 in counteracting tabun poisoning and its effectiveness even at lower concentrations suitable for human use. The significant improvement in the therapy of tabun-poisoned experimental models makes K203 a leading antidote for tabun poisoning.

\section{Acknowledgement}

We wish to thank Jasna Mileković, Marija Kramarić, and Mirjana Matašin for technical assistance. This work was supported by the Ministry of Science, Education and Sports of the Republic of Croatia (Grant No. 022-0222148-2889 and No. 022-0222148-2139) and by NATO (CBP.EAP. RIG.981791 and CBP.EAP.CLG 983024).

\section{REFERENCES}

1. Dawson RM. Review of oximes available for the treatment of nerve agent poisoning. J Appl Toxicol 1994;14:317-31.

2. Johnson MK, Jacobsen D, Meredith TJ, Eyer P, Heath AJ, Ligtenstein DA, Marrs TC, Szinicz L, Vale JA, Haines JA. Evaluation of antidotes for poisoning by organophosphorus pesticides. Emerg Med 2000;12:22-37.

3. Sheridan RD, Beeson D, Tattersall JEH. Non-competitive block of the human muscle adult nicotinic acetylcholine receptor ion channel by the bispyridinium compounds, SAD-128 (SAD), toxogonin (TOX) and HI-6. Eur J Neurosci 2000;12(Suppl. S):36.

4. Stojiljković MP, Jokanović M. Pyridinium oximes: rationale for their selection as causal antidotes against organophosphate poisonings and current solutions for auto-injectors. Arh Hig Rada Toksikol 2006;57:435-43.

5. Shih TM, Koviak TA, Capacio BR. Anticonvulsants for poisoning by the organophosphorus compound soman: Pharmacological mechanisms. Neurosci Biobehav Rev 1991;15:349-62.

6. Shih TM, McDonough JH, Koplovitz I. Anticonvulsants for soman-induced seizure activity. J Biomed Sci 1999;6:8696.

7. Thiermann H, Szinicz L, Eyer P, Felgenhauer N, Zilker $\mathrm{T}$, Worek F. Lessons to be learnt from organophosphorus pesticide poisoning for the treatment of nerve agent poisoning. Toxicology 2007;233:145-54.

8. Thiermann H, Szinicz L, Eyer F, Worek F, Eyer P, Felgenhauer N, Zilker T. Modern strategies in therapy of organophosphate poisoning. Toxicol Lett 1999;107:233-9.

9. Eto M. Organic and biological chemistry. In: Zweig G, editor. The Organophosphorus Pesticides. Cleveland: CRC Press Inc.; 1976. p. 142.

10. Hamilton MG, Lundy PM. HI-6 therapy of soman and tabun poisoning in primates and rodents. Arch Toxicol 1989;63:144-9.

11. Maksimović M, Bošković B, Radović L, Tadić V, Deljac $\mathrm{V}$, Binenfeld Z. Antidotal effects of bis-pyridinium-2monooxime carbonyl derivatives in intoxications with highly toxic organophosphorus compounds. Acta Pharm Jugoslav 1980;30:151-60.

12. Jokanović M, Maksimović M, Kilibarda V, Jovanović D, Savić D. Oxime-induced reactivation of acetylcholinesterase inhibited by phosphoramidates. Toxicol Lett 1996;85:35-9.

13. Čalić M, Lucić Vrdoljak A, Radić B, Jelić D, Jun D, Kuča $\mathrm{K}$, Kovarik Z. In vitro and in vivo evaluation of pyridinium oximes: Mode of interaction with acetylcholinesterase, effect on tabun- and soman-poisoned mice and their cytotoxicity. Toxicology 2006;219:85-96.

14. Lucić Vrdoljak A, Čalić M, Radić B, Berend S, Jun D, Kuča K, Kovarik Z. Pretreatment with pyridinium oximes improves antidotal therapy against tabun poisoning. Toxicology 2006;228:41-50.

15. Kovarik Z, Čalić M, Bosak A, Šinko G, Jelić D. In vitro evaluation of aldoxime interactions with human acetylcholinesterase. Croat Chem Acta 2008;81:47-57.

16. Kovarik Z, Čalić M, Šinko G, Bosak A, Berend S, Lucić Vrdoljak A, Radić B. Oximes: Reactivators of phosphorylated acetylcholinesterase and antidotes in therapy against tabun poisoning. Chem Biol Interact 2008;175:173-9. 
17. Berend S, Lucić Vrdoljak A, Radić B, Kuča K. New bispyridinium oximes: In vitro and in vivo evaluation of their biological efficiency in soman and tabun poisoning. Chem Biol Interact 2008;175:413-6.

18. Čalić M, Bosak A, Kuča K, Kovarik Z. Interactions of butane, but-2-ene or xylene-like linked bispyridinium para-aldoximes with native and tabun-inhibited human cholinesterases. Chem Biol Interact 2008;175:305-8.

19. Musilek K, Jun D, Cabal J, Kassa J, Gunn-Moore F, Kuca K. Design of a potent reactivator of tabuninhibited acetylcholinesterase-synthesis and evaluation of (E)-1-(4-carbamoylpyridinium)-4-(4-hydroxyiminomethylpyridinium)-but-2-ene dibromide (K203). J Med Chem 2007;50:5514-8

20. Kovarik Z, Čalić M, Šinko G, Bosak A. Structure-activity approach in the reactivation of tabun-phosphorylated human acetylcholinesterase with bispyridinium para-oximes. Arh Hig Rada Toksikol 2007;58:201-9.

21. Šinko G, Čalić M, Kovarik Z. para- and ortho-Pyridinium aldoximes in reaction with acetylcholinesterase. FEBS Letters 2006;580:3167-72.

22. Šinko G, Čalić M, Bosak A, Kovarik Z. Limitation of the Ellman method: Cholinesterase activity measurement in the presence of oximes. Anal Biochem 2007;370:223-7.
23. Thompson WR. Use of moving averages and interpolation to estimate median effective dose. Bacteriol Rev 1947;11:11545.

24. Weil CS. Tables for convenient calculation of medianeffective dose (LD50 or ED50) and instruction in their use. Biometrics 1952;8:249-63.

25. Ellman GL, Courtney KD, Andres VJ, Featherstone RM. A new and rapid colorimetric determination of acetylcholinesterase activity. Biochem Pharmacol 1960;7:8895.

26. Thiermann H, Mast U, Klimmek R, Eyer P, Hibler A, Pfab R, Flegenhauer N, Zilker T. Cholinesterase status, pharmacokinetics and laboratory findings during obidoxime therapy in organophosphate poisoned patients. Hum Exp Toxicol 1997;16:473-80

27. Eddleston M, Szinicz L, Eyer P, Buckley N. Oximes in acute organophosphorus pesticide poisoning: a systemic review of clinical trials. Qjm-Mon J Assoc Phys 2002;95:275-83.

28. Kalász H, Hasan MY, Sheen R, Kuča K, Petroianu G, Ludányi K, Gergely A, Tekes K. HPLC analysis of K-48 concentration in plasma. Anal Bioanal Chem 2006;385:10627. 
Sažetak

\section{PROCJENA OKSIMA K203 KAO ANTIDOTA PRI OTROVANJU TABUNOM}

Proučavali smo bispiridinijski oksim K203 [(E)-1-(4-karbamilpiridinij)-4-(4-hidroksiiminometilpiridinij)but-2-ene dibromid] u uvjetima in vitro - studirajući njegove interakcije s ljudskom acetilkolinesterazom (AChE) i butirilkolinesterazom (BChe) inhibiranim tabunom te u uvjetima in vivo - određivanjem njegova antidotskog učinka na miševe i štakore otrovane tabunom. Radi usporedbe uključili smo rezultate dobivene s oksimima K048 i TMB-4 kao najučinkovitijim oksimima kod otrovanja tabunom.

K203 je potpuno reaktivirao AChE inhibiranu tabunom sa sveukupnom brzinom reaktivacije od $1806 \mathrm{~L}$ $\mathrm{mol}^{-1} \mathrm{~min}^{-1}$ što ga svrstava u najučinkovitije reaktivatore AChE inhibirane tabunom. K203 je reverzibilno inhibirao AChE $\left(K \mathrm{i}=0,090 \mathrm{mmol} \mathrm{L}^{-1}\right)$ i $\mathrm{BChE}\left(K \mathrm{i}=0,91 \mathrm{mmol} \mathrm{L}^{-1}\right)$ pokazujući svoja in vitro zaštitna svojstva od inhibicije tabunom. Terapija dozom K203 od 1/4 njegove $L_{50}$ omogućila je preživljavanje svih miševa nakon otrovanja dozom tabuna od $8,0 \mathrm{LD}_{50}$. Time je $\mathrm{K} 203$ pokazao bolju učinkovitost u usporedbi s K048 ili TMB-4. K tome, K203 je značajno zaštitio štakore od otrovanja tabunom kompenzirajući toksični učinak tabuna na aktivnost kolinesteraze i do 60 min nakon trovanja. Pokazano poboljšanje terapeutske učinkovitosti K203 ističe ovaj oksim pretečom za daljnji razvoj antidota u otrovanju tabunom.

KLJUČNE RIJEČI: acetilkolinesteraza, butirilkolinesteraza, K048, TMB-4, piridinijski oksim, tabun, živčani bojni otrovi

CORRESPONDING AUTHOR:

Zrinka Kovarik, Ph.D.

Institute for Medical Research and Occupational Health POB 291, HR-10001 Zagreb, Croatia

E-mail:zrinka.kovarik@imi.hr 